\title{
Taxation Income, Graft and Informal Sector Operations in Nigeria in Relation to Other African Countries
}

\author{
Cordelia Onyinyechi Omodero ${ }^{1}$ \\ ${ }^{1}$ Clifford University Owerrinta, Abia State, Nigeria \\ Correspondence: Cordelia Onyinyechi Omodero, Clifford University Owerrinta, Abia State, Nigeria.
}

Received: December 17, 2019

Accepted: January 24, 2020

Online Published: March 17, 2020

doi:10.5430/ijfr.v11n2p163

URL: https://doi.org/10.5430/ijfr.v11n2p163

\begin{abstract}
This study investigates the influence of the informal sector and graft on income accruing to the government through taxation in Nigeria. Informal economy and graft are the two critical activities that inhibit government tax revenue collection and negatively affect the performance of an effective government. The study employs secondary data that cover a period from 2000 to 2018. This period is the millennium period which the country is expected to overcome corruption and curtail the level of informal economic activities prevailing in the nation, but it appears that all efforts seem not to be yielding the required results. In order to achieve the objective of this study, the multi-regression analysis is performed and the results indicate that corruption is very harmful to tax revenue collection while the informal economy has no significant impact on tax revenue within the millennium period covered by this study. Thus, the study suggests formalization of legal unofficial economy activities and total eradication of corruption in Nigeria through the strengthening of the anti-graft agencies, reinforcement of the legal structure and introduction of a more severe penalty for the perpetrators.
\end{abstract}

Keywords: informal economy, graft, taxation revenue, government, Nigeria

JEL Codes: O17, H20, D73

\section{Introduction}

Taxation income is usually a major income source of the government which enables her to fulfill her social obligations to the public. Omodero and Dandago (2019) submit that, the government cannot achieve proper public service delivery except the citizens are committed to payment of taxes as part of their civic responsibility. On the contrast, informal sector has provided emerging economies the opportunity to increase the growth of their economy and also suffer the unfavourable consequence of high rate of tax evasion. Tax evasion is a product of the informal sector activities which have over the years robbed the government of nations the taxation income that should have accrued to the government but are hidden from the authorities (Omodero, 2019). Informal economy and graft have a typical affiliation and their presence out of an economy has all the earmarks of being a characteristic wonder. As such, it is expected that one cannot be available without the existence of the other. Informal economy is synonymous with shadow economy and contains all unregistered financial exercises and pay which add to the officially observed Gross National Product (Chen and Schneider, 2018). Unofficial economy additionally alludes to legitimate items and administrations that escape the open specialists (Putnins and Sauka, 2014). On the other hand, graft is a cankerworm that exhausts the textures of an economy and lessens a country's respectability before the worldwide network (Omodero \& Dandago, 2018). Borlea, Achim and Miron (2017) allude to informal economy and graft as two hurtful endeavors that mutually undermine majority rule administration, legitimate system and monetary headway. In spite of the fact that it is accepted that corruption upgrades financial development particularly in advancing nations like Nigeria where there is clear frail administrative structure and debasement taking out organization and quicken business exchanges, yet defilement has inbuilt subjective ruinous highlights that avert genuine monetary advancement of a country. In a similar way, it has been built up that shadow economy contributes 65 percent of Nigeria's GDP (International Monetary Fund, 2017) because of high pace of joblessness, debasement and independent work. Bologna (2015) declares that shadow economy and defilement supplement one another thus, the greater the size of the underground economy, the higher the pace of debasement. As a result the economy is said to be growing with the trend while the government stands to lose revenues through non-payment of taxes by the informal economy players. 
As per Petrescu (2016) individuals who do non-crimes in the casual division ordinarily think that it is hard to change to the formal area. Those that connect with into crimes during authorizations, additionally reject openings for work in the official work market notwithstanding when the approvals have been disposed of (Petrescu, 2016). The situation is to such an extent that the casual specialists misjudge the significance of training and don't put resources into their very own instruction and that of their kids since they have the understanding that the casual work market extends employment opportunities with next to zero formal instruction (Petrescu, 2016). Regardless of the various advantages owing to shadow economy and debasement, in all actuality shadow economy is the significant reason for tax avoidance which diminishes government income. At the point when government income diminishes because of unreported earnings, at that point the legislature will be monetarily handicap and there will be deficient store to give open products and enterprises (Hassan, 2017). The presence of underground economy may not really adversely affect the economies where the exercises are winning, yet the administrations of those nations bring about colossal duty income misfortunes and most occasions the work guidelines are damaged (Nchor and Konderla, 2016).

Then again, if citizens see that debasement is winning in a nation, they will lose trust in the legislature and might be reluctant to play out their municipal obligation of settling regulatory expenses (Bird, MartinezVasquez and Torgler, 2008). Defilement affects charge organization and reviews just as the believability of the establishments, consequently following the degree of debasement in a nation, citizens are persuaded to participate in casual segment so as to sidestep charge (Hunady and Orviska, 2015). Also, Aruba (2010) sets that the decrease in residents' trust in their administration is one of the outcomes of defilement clear in absence of straightforwardness and narrow-minded demonstrations of government authorities. Be that as it may, the test of assessment profound quality improves debasement (Ogunc and Yilmaz, 2000) and the circumstance will more often than not impact charge income and monetary movement (Ivanyna, Moumouras and Rangazas, 2016). The motivation behind why numerous organizations stay casual may not exclusively be to avoid charge, yet rather, the perplexing expense framework, guideline troubles and the expenses of formalization of organizations that are less efficient (Joshi, Prichard and Heady, 2014). Shadow economy is typically advanced by assessment framework flaws, wasteful open division and carefully managed work showcase (Gaspareniene, Remeikiene and Heikkila, 2016).

\subsection{Objective of the Study}

The major objective of this study is to determine the impact of informal economy and graft on tax revenue collection in Nigeria. The study is also concerned with the following specific objectives:

1. To examine the impact of informal economy on tax revenue collection in Nigeria.

2. To evaluate the influence of graft on tax revenue collection in Nigeria.

\subsection{Research Hypotheses}

In order to achieve the above research objectives this study is guided by the following hypotheses:

Ho1: Informal economy does not have substantial influence on tax revenue collection in Nigeria.

Ho2: Graft does not significantly affect tax revenue collection in Nigeria.

\section{Literature review}

\subsection{Theoretical Approaches Determining Informal Economy}

Informal economy could be assessed directly and indirectly. The direct approach involves the use of survey and tax audit.

\subsubsection{Direct Approach}

The immediate methodology includes utilizing study and assessment review to build up the size of the shadow economy. The study strategy is regularly stood up to with the danger of error of the complete size of the shadow economy because of absence of believability of the criticisms and at some point zero reaction from the respondents attributable to the fragile idea of the subject (Putnins and Sauka, 2015). Conversely, the censure is that the direct approach does not correctly assess the magnitude of the informal sector operations prevailing in an economy, since the valuation is reliant on the information definite persons are ready to make available, which still depends on their readiness to give factual responses to the enquiries and also to allow meetings and conversations (Omodero, 2019). Be that as it may, it is incredibly critical to be completely mindful of the reasons for the casual segment exercises, their strategies for activity and approaches to avoid the beguiling endeavors to sidestep charge. This is fundamental since bookkeeping data may be mistaken somewhat and the smaller scale and macroeconomic inclination to show gross picture of accessible assets in a false way (Opet, Turcas, Dumiter and Brezeanue, 2017) probably won't be 
distinguished in an expense review. In Nigeria, charge review is typically completed by the Federal Inland Revenue Service (FIRS) and State Board of Internal Revenue (SBIR) contingent upon the kind of duty the review is intended for. In any case, the two bodies, as in different nations set out on duty review to build up the size of shadow economy through the degree of tax avoidances the review exercise will uncover. Somewhat, charge review more often than not uncovers undeclared assessable pay and it gives a gauge of the size of the shadow economy.

\subsubsection{Roundabout Methodologies}

The roundabout methodologies recognized by (Schneider and Enste, 2000) include: national bookkeeping insights approach, exchange approach, money request approach, power utilization approach and Multiple Indicators, Multiple Causes (MIMIC) approach set up by (Vuletin, 2008; Schneider, 2010; Abdih and Medina, 2016). With the end goal of this examination, three applicable aberrant methodologies have been chosen and they are: the exchange approach, money request approach and MIMIC methodology.

\subsubsection{The Exchange Approach}

The exchange approach utilizes information assembled on the general exchanges in the economy which speak to both the official and informal Nominal GDP, therefore the assessed size of the shadow economy is subtracted from the all-out Nominal GDP. In Nigeria, the Nominal GDP comprises of commitments from both authority exercises and informal exercises (shadow economy). In 2017, casual economy contributed about $65 \%$ of the Nigeria's Nominal GDP (IMF, 2017) and its main part is gotten from the agrarian area. This investigation utilizes the assessed size of the shadow economy communicated as level of absolute Nominal GDP for the period under examination. Addendum 1 beneath demonstrates that the development of shadow economy in Nigeria has been expanding at a disturbing rate since 2016 affirming the IMF (2017) accommodation that casual part is adding to the economy more than the formal division. Nonetheless, in spite of the contribution of the shadow economy, the truth of the matter is that the pay from the casual area is normally unreported thus the administration loses generous pay that would have been earned through expense income.

\subsubsection{Money Request Approach}

Money request approach depends on the presumption that shadow exchanges are attempted with money so as to abstain from leaving a proof that could be discernible by the experts (Tanzi, 1980; 1983; 1999; Feige and Urban, 2008). This is the tallness of defilement and the motivation behind why it is accepted that shadow economy and debasement are interconnected in light of the fact that they cooperate. Where there are casual exercises, defilement is available with every one of its highlights since every one of the individuals that will hide the money exchanges more likely than not got a lot of the fix so as to close their mouths. On the off chance that there is nobody to unveil the money exchanges that have occurred, even the expense review can't uncover it since there are no records, receipts or even outsider confirmations.

\subsubsection{Multiple Indicator Multiple Cause (MIMIC) Methodology}

Different Indicator Multiple Cause (MIMIC) methodology mulls over the various reasons for shadow economy just as the few impacts of the casual economy on different territories of the economy. This methodology utilizes both the unmistakable and the careful factors causing shadow economy and the resultant impacts of the casual segment (Abdih and Medina, 2016, Schneider, 2010, Vuletin, 2009). The figure 1 beneath gives a pictorial delineation of elements causing shadow economy in Nigeria and the impacts of the casual area in the nation.

From figure 1 underneath, the MIMIC methodology portrays that duty risk, administrative weight, joblessness rate, defilement and independent work are real determinants of shadow economy in the nation which thusly helps Nominal GDP development, offers the open a chance to retain unreported salary and causes charge income misfortunes for the legislature. Casual economy yield that could be assessable salary is considered as expense income misfortune on the grounds that the casual area members or specialists similarly advantage from the open products and ventures given by the legislature through duty incomes got from the dedicated natives (Anwar, Akbar, Akbar, and Azhar, 2017). 


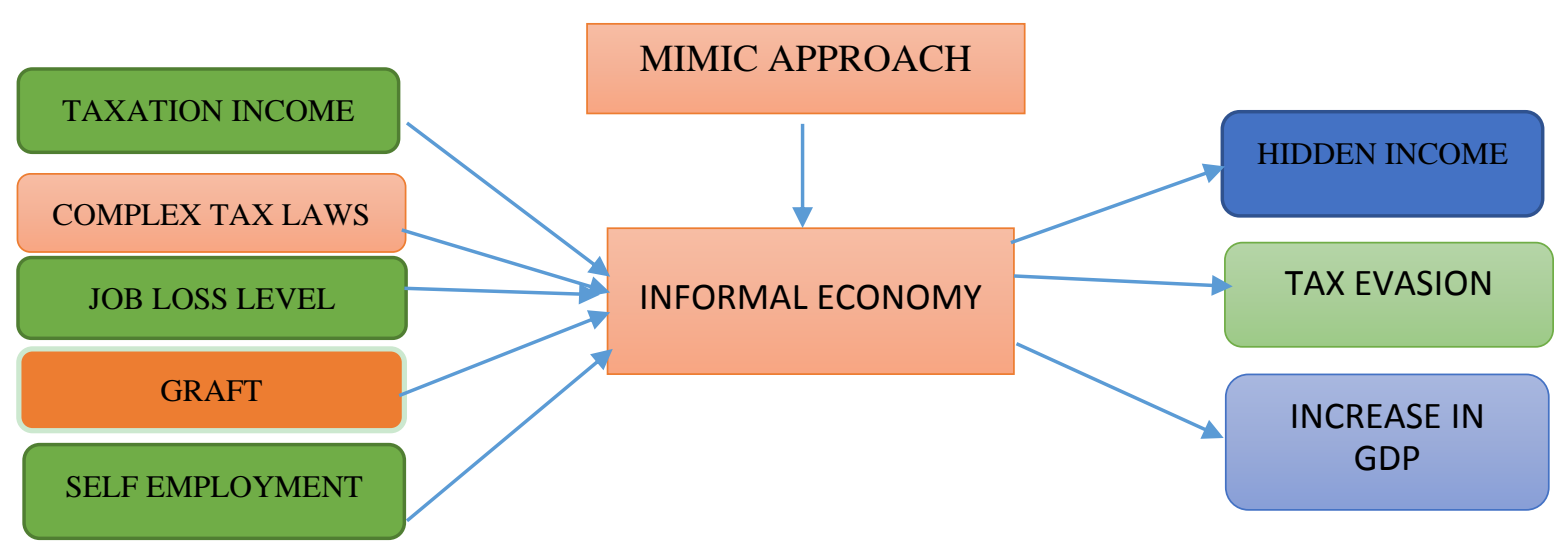

Figure 1. MIMIC approach of measuring informal sector operations

Source: Author's Desk Research, 2020

A portion of the factors in figure 1 above are quantifiable, for example the Nominal GDP, while others are basically subjective in nature and must be felt. Models are the administrative weight and debasement, despite the fact that the Transparency International thought of a record called defilement observation file which by and by decides the degree of degenerate exercises winning in practically every one of the nations on the planet.

\subsection{Empirical Review}

Tedika and Mutascu (2013) examined the impacts of shadow economy on duty incomes of a few African Countries utilizing board model methodology. The information utilized for the investigation secured a period from 1999 to 2007 and the discoveries uncovered that shadow economy had a critical negative effect on duty incomes of the chose African Countries. The investigation recommended that African governments should try to oversee shadow economy events to maintain a strategic distance from ensuing reductions in the degree of assessment income. Tatariyanto (2014) utilized Multiple Indicator and Multiple Cause (MIMIC) way to deal with inspect the size of underground economy and loss of assessment income in Indonesia from 2000 to 2008. The examination discovered proof that underground economy expanded when huge number of individuals were not submitting government forms because of changes in assessment strategy and development in the pace of joblessness. The examination likewise uncovered that underground economy in Indonesia diminished spin-off of a more noteworthy open attention to agree to charge installment as a major aspect of their community commitments. Muchiri (2014) mulled over the failure of assessment income to meet the use prerequisites of the administration in Kenya because of the presence of shadow economy notwithstanding when a few changes in tax collection have been executed. The examination utilized normal least squares (OLS) strategy and optional type of information, in this manner the outcome demonstrated that an expansion in the size of the casual segment prompts a lessening in income execution and the other way around, which is quantitatively huge. The investigation additionally found that the key elements deciding assessment income execution in Kenya incorporate remote direct venture, per capita GDP and receptiveness to exchange. The investigation recommended detailing of approaches that would incorporate casual part in the expense section which ought to include cultivating of intentional assessment consistence and decrease of duty accumulation costs.

Barbara and Claudio (2015) connected reenactment based examination to survey the impacts of a few expense changes in the economy of Italy because of the test of tax avoidances coming about because of undeclared employments and organizations. The specialists built different expense change models and concocted a few outcomes which uncovered that macroeconomic and welfare impacts of assessment changes may be horrifyingly thought little of if shadow economy were to be neglected. Likewise, deducting the expense of work from the business assessment base would be an exaggeration and could be hindering to the size of the shadow economy. Further discoveries demonstrated that shadow economy could be diminished forever through varieties in the expense blend which could likewise decrease the work charge. Hunady and Orviska (2015) assessed the impact of defilement on duty income in 46 OECD and Latin America Countries utilizing information that secured a period from 1998 2013. The examination utilized fixed and irregular impact models and the outcomes demonstrated that debasement had a huge negative impact on absolute assessment income. Further evaluation was completed utilizing the expense 
income, the examination additionally discovered solid proof that defilement affected all the more adversely on assessments from merchandise and ventures. Shahab, Pajooyan and Ghaffari (2015) utilized 25 nations including both created and creating nations to look at the impact of debasement on shadow economy from $1999-2007$. The investigation discovered proof that the connection among debasement and shadow economy shifted by the degree of defilement winning in every nation.

Gaspareniene et al. (2016) checked on the effect of shadow economy determinants on the size of shadow economy in Ukraine from 2005-2012. The examination uncovered that 99 percent of shadow economy in Ukraine was dictated by factors, for example, charge rate, in general business rate, import of products and ventures, GDP and investment of working age individuals in the work showcase. In attempting to investigate the components that reason the presence of shadow economy in nations, Hassan and Schneider (2016) connected MIMIC way to deal with explore the size and improvement of the shadow economies of 157 nations from 1999 to 2013, the examination discovered proof that higher assessment, joblessness rates and administrative weights were the significant determinants of the shadow economy. The discoveries further unveiled that from 1999 to 2013, casual economy represented 33.77\% of authority GDP of 157 nations which contained high salary OECD nations, Central Asian Eastern European and furthermore the creating nations. Mawejje and Munyambonera (2016) utilized quarterly information from 1999 to 2013 and ARDL limits testing procedures to examine the determinants of duty income execution in Uganda. The outcomes demonstrated that the shadow economy and horticultural segment had the biggest obstructions to charge income execution while exchange transparency, improvement consumptions and modern area development had positive association with assessment income execution.

Nchor and Konderla (2016) utilized cash request way to deal with research the size of the shadow economy of Czech Republic and the inferable misfortunes in expense income. The methodology estimated two phases of shadow economy which incorporated the econometric estimation of a total cash request and the figuring of the incentive through the amount hypothesis of cash. The investigation found that the shadow economy of Czech Republic on the normal was about $20.9 \%$ as toward the part of the arrangement that the nation loses a normal of expense income of about $7.2 \%$ of GDP every year. Borlea et al. (2017) explored the effect of defilement and shadow economy on financial development of the European Union Countries from 2005 to 2014. The discoveries showed that debasement and shadow economy had a solid relationship and those two on the whole impacted monetary development of the European Countries fundamentally and adversely. Subside (2017) inspected the effect of shadow economy on assessment income execution in Zimbabwe utilizing conventional least squares (OLS) technique and yearly time arrangement information from 1980 to 2015 . The relapse results showed among others that shadow economy had a positive and critical effect on duty income. The finding of Peter (2017) isn't in accordance with the idea of shadow economy which is known for covering pay to dodge charge, and if business and individual earnings are not uncovered with the goal for specialists to charge, how at that point can shadow economy have a critical positive effect on expense income. At the end of the day, it is expected that some type of duties in Zimbabwe are overcome shadow economy for it to have positive effect on expense income.

Awasthi and Engelschalk (2018) thought about the connection among tax collection and the shadow economy and how the assessment framework can animate and implement the formalization of business exercises. The investigation found the presence of solid negative connection between assessment income accumulation and the casual economy. The discoveries further demonstrated that measures to get casual economy into covering government expense must be comprehensive and include some type of conventional methodology of observing and utilization of law authorization devices which may require charge authorities getting entrance into the information base of the casual economy members, including third data from different open and private sources just as banks. Guillermo and Deyvi (2018) examined the effect of casual economy on expense incomes and financial development utilizing a board information of OECD individuals and Latin America nations from 1995 to 2016. The investigation utilized a MIMIC methodology and Generalized Moment Method (GMM) so as to set up the effect of the size of the casual economy on financial development and duty income accumulation. The discoveries uncovered that the evaluated normal size of the casual economy as a level of the GDP for Latin America Countries was 34\% while, on account of the OECD Countries, it was $19.83 \%$. From the outcomes, the nation with the biggest size of informal economy in Latin America was Peru, with a size of $37.4 \%$ of the GDP for 2016 while for OECD Countries, Turkey had the most elevated informal economy with a size of $29.75 \%$ of the GDP for 2016. The outcomes likewise demonstrated that the Latin America nation with the littlest size of casual economy was Uruguay with $14.47 \%$ while that of OECD was Denmark with $12.84 \%$, both for 2016. Nonetheless, the investigation for the most part found that for both Latin America and OECD nations, the casual economy negatively affected the measure of assessment income gathered by the administration. 


\subsection{Research Gap}

This present study is organized to show the impact of informal economy and corruption on tax revenue in Nigeria from 2000 to 2018. The study depicts what the Nigerian experience has been in this millennium period as regards the influences of informal economic activities and corrupt practices on government income owing to the fact that tax revenue is required to provide goods and services to the citizens. The size of shadow economy utilized is the level of the Nominal GDP speaking to the commitment from the casual area and the level of defilement is connected rather than the debasement observation file (CPI) values. Albeit other unquantifiable factors deciding casual economy and constantly adding to assess income misfortunes are considered in principle, be that as it may, the significant point is to exactly decide the impact of casual economy and defilement on expense income produced in Nigeria.

\section{Methodology}

\subsection{Research Design}

This examination utilized a semi exploratory plan so as to accomplish the goals of the investigation. Here the exploration embraced the econometric examination methods of conventional least squares (OLS) different relapse system. This exploration configuration is required on the grounds that the assigned research zone for assessment is expository, experimental and quantitative in nature where the reliant and free factors are seen over a timeframe for any deviation that can possibly emerge.

\subsection{Types and Sources of Data Collection}

The examination utilized optional type of information in light of the fact that the reason for this exploration is to create an experimental proof around there of concentrate particularly in this thousand year's timeframe. Time arrangement information identifying with the ward and indicator factors utilized in this examination secured a period from 2000 to 2018. The casual (shadow) economy is a level of the Nominal GDP of Nigeria while the degree of defilement is the worth gotten in the wake of netting up the debasement discernment list (CPI) material to Nigeria by 100 and subtracting the incentive from 100. The reason is that CPI worth speaks to the level of opportunity from defilement and it is partitioned by 10 , and when a similar worth is increased by 100 , it very well may be subtracted from 100 to land at the degree of debasement winning in a specific nation. The assessment income is communicated in billions of Naira (neighborhood cash), along these lines to accomplish consistency because of inconsistency of the qualities, every one of the information have been communicated in their logarithm structure. The degree of noteworthiness picked for this investigation is $5 \%$, along these lines the individual consequence of the factors will be critical at 5\%. Every one of the information utilized in this investigation were gathered from the Central Bank of Nigeria Statistical Bulletin, International Monetary Fund and Transparency International.

\subsection{Model Specification}

The functional and econometric relationship between the response variable and the predictor variables are seen in the equation below:

$$
\begin{gathered}
\text { TXRV }=\mathrm{f}(\text { SDWY }, \text { LCRP }) \\
\text { LOGTXRV }=\beta_{0}+\beta_{1} \text { LOGSDWY }+\beta_{2} \text { LOGLCRP }+\mu
\end{gathered}
$$

Where: TXRV $=$ Tax revenue; SDWY $=$ Shadow economy; LCRP $=$ Level of corruption; $\beta_{0}=$ Constant; $\beta_{1}-\beta_{2}=$ Regression coefficients; $\mu=$ Error term.

On the a priori, we expect; $\beta_{1}<0, \beta_{2}<0$. 


\section{Data Analysis and Interpretations}

\subsection{Trend Analysis}
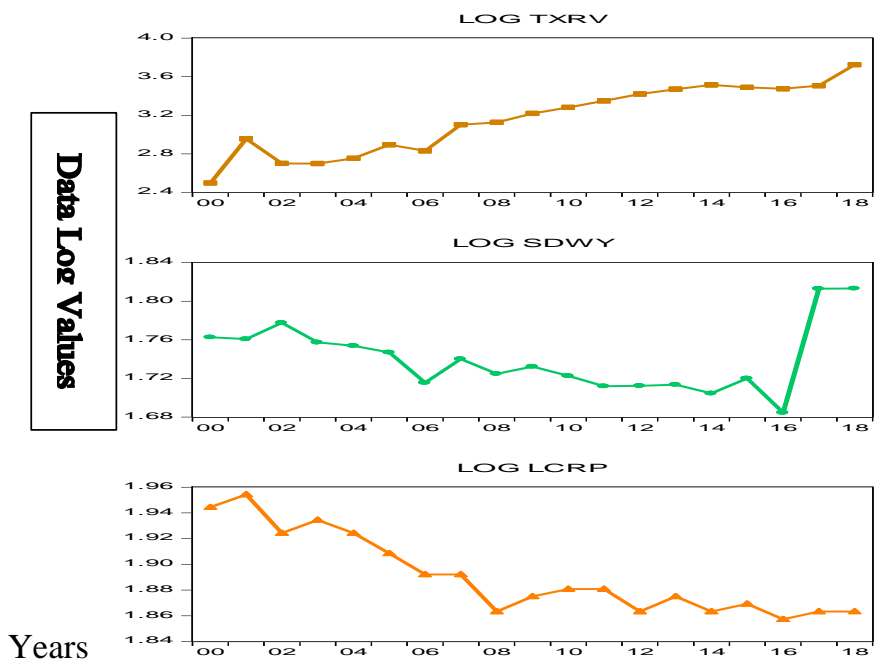

Figure 2. Trend of data from 2000 to 2018

Sources of Data: Central Bank of Nigeria Statistical Bulletin, International Monetary Fund and Transparency International

Figure 1 above provides evidence that informal economy and level of corruption from 2016 to 2018 have remained unchanged, although tax revenue has been improving.

Table 1. Model summary of results

\begin{tabular}{llllll}
\hline Model & $\mathrm{R}$ & $\mathrm{R}$ Square & Adjusted R Square & Std. Error of the Estimate & Durbin-Watson \\
\hline 1 & .871 & .759 & .729 & .18367 & 1.872 \\
\hline
\end{tabular}

a. Predictors: (Constant), LOGLCRP, LOGSDWY

b. Dependent Variable: LOGTXRV

Source: Author's computation, 2020

From Table 1 above, the correlation (R) value is $87.1 \%$ which infers that the relationship between tax revenue and the explanatory variables is very strong. The coefficient of determination has a value of $75.9 \%$ indicating that graft and informal economy describe up to $75.9 \%$ of the changes in tax revenue while the remaining $24.1 \%$ are attributable to other variables that were not considered in the model. The Durbin-Watson of 1.87 which is approximately 2 , suggests absence of auto- correlation.

Table 2. ANOVA

\begin{tabular}{lllllll}
\hline Model & & Sum of Squares & df & Mean Square & F & Sig. \\
\hline \multirow{3}{*}{1} & Regression & 1.703 & 2 & .851 & 25.237 & .000 \\
\cline { 2 - 7 } & Residual & .540 & 16 & .034 & & \\
\cline { 2 - 7 } & Total & 2.242 & 18 & & &
\end{tabular}

a. Dependent Variable: LOGTXRV

b. Predictors: (Constant), LOGLCRP, LOGSDWY

Source: Author's calculation, 2020 
Table 2 above provides the regression result of F-statistic. The value is 25.237 while the p-value is $0.000<0.05$ level of significance. The result shows that the model is statistically significant and fit for the study. However, the result simply implies that shadow economy and corruption jointly affect tax revenue collection significantly. This confirms the assertions that shadow economy and corruption are unified forces that exist simultaneously in an economy and have the capacity to ruin an economic system, result to tax revenue losses and make the government incapable of providing public goods and services to the citizenry.

\subsection{Test of Hypotheses}

Table 3. Coefficients

\begin{tabular}{|c|c|c|c|c|c|c|c|c|}
\hline \multirow[t]{2}{*}{ Model } & & \multicolumn{2}{|c|}{$\begin{array}{l}\text { Unstandardized } \\
\text { Coefficients }\end{array}$} & \multicolumn{2}{|c|}{$\begin{array}{l}\text { Standardized } \mathrm{t} \\
\text { Coefficients }\end{array}$} & \multirow[t]{2}{*}{ Sig. } & \multicolumn{2}{|c|}{$\begin{array}{l}\text { Collinearity } \\
\text { Statistics }\end{array}$} \\
\hline & & B & Std. Error & Beta & & & Tolerance & VIF \\
\hline \multirow{3}{*}{1} & (Constant) & 20.202 & 2.964 & & 6.815 & .000 & & \\
\hline & LOGSDWY & 1.394 & 1.321 & .137 & 1.055 & .307 & .888 & 1.126 \\
\hline & LOGLCRP & -10.296 & 1.476 & -.908 & -6.974 & .000 & .888 & 1.126 \\
\hline
\end{tabular}

a. Dependent Variable: LOGTXRV

Source: Author's computation, 2020

Table 3 shows the regression results of all the independent variables and the result of the multicollinearity test. From table 3, the Variance-Inflatory Factor (VIF) of each predictor variable is less than 10 which shows the absence of multicollinearity (Gujarati \& Porter, 2009). The multicollinearity test is carried out to ensure that the independent variables do not interrelate with each other. The rule is that if the Variance-Inflatory Factor (VIF) of any predictor variable is above 10, it suggests the existence of a multicollinearity in the sample (Gujarati \& Porter, 2009). However, the VIF of all the independent variables on table 3 above are far below 10, thus there is absence of multicollinearity. The regression result indicates that informal economy (LOGSDWY) t-statistic value is 1.055 and the p-value is $0.307>0.05$. Thus, $\mathrm{Ho}_{1}$ which states that informal economy does not have substantial influence on tax revenue is accepted and the alternative which suggests otherwise declined. This result discloses that informal economy has no impact on the tax revenue. This result conflicts with the findings of (Tedika \& Mutascu, 2013; Nchor \& Konderla, 2016; Borlea et al., 2017; Guillermo \& Deyvi, 2018) whose studies found evidence that shadow economy had a significant negative impact on tax revenue. The result also refutes the findings of Peter (2017) whose work established that shadow economy had a significant positive impact on tax revenue in Zimbabwe.

On the other hand, the t-statistic for level of corruption (LOGLCRP) is -6.974 with the p-value of $0.000<0.05$ significance level. This result implies that corruption has a robust significant negative impact on tax revenue in Nigeria. Therefore, $\mathrm{Ho}_{2}$ is overruled and the alternative which states otherwise recognized. This result is in harmony with the findings of (Hunady \&Orviska, 2015; Borlea et al., 2017) among others.

\section{Conclusion and Recommendations}

\subsection{Conclusion}

The consequences of the examination have uncovered that both shadow economy and defilement go with negative impacts on assessment income execution in Nigeria. Aside from defilement, a few elements have been recognized as the real determinants of shadow economy in Nigeria, for example the high pace of joblessness, independent work, taxation rates and administrative weights. Millennium Development Goal to alleviate poverty through job creation (Omodero, 2019) cannot be achieved if corruption keeps prevailing and tax revenue being diverted through informal sector operations. These are regular determinants of the casual area in Nigeria and the worry is that, they all lead to taxation income misfortunes since the pay got from the casual economy is not revealed because it is a quick money transfer arrangement type. There is virtually no formal or proper transaction process. The submission is that as the administration losses income through shadow economy and defilement heightens, it gives space for lacking arrangement of open products and ventures. As such, the legislature will be handicap and will neglect to play out its obligations to people in general. The implication is that, the desire for people in general from the administration will not be met because of deficient reserve occasioned by income spillages through tax avoidances and evasions. In spite of the fact that shadow economy prompts development in the Nominal GDP, however the impact on assessment income is not great to the administration. 


\subsection{Recommendations}

1. It is presently very essential for the government to move the fight against corruption to an advanced level. Graft enhances informal economy operations and should be managed cautiously in other to reinstate the sureness of the tax payers whose loyalty have been compressed due to the level of graft among government officials. Well industrialized countries that have overcome the menace of corruption should be emulated and the fight should be more concentrated on those at the hemp of affairs in Nigeria.

2. Job creation is part of the Millennium Development goal to alleviate poverty in Nigeria (Omodero, 2019). Thus, availability of formal employments will help to minimize tax evasion because those in official employment cannot hide their income since taxes are part of the legal deductions made at source and are hence being sent to the authorities. Hence, the study recommends job availability for the jobless youths and those within the working class age.

3. The study is also suggesting that the causes of informal economy activities such as unemployment, regulatory burdens and complex tax laws should be improved in order to encourage citizens to formalize their economic activities and disclose their incomes.

4. The government is encouraged to improve on public service delivery which is the major reason citizens find it very comfortable to hide their income as almost all the infrastructures in the country are in a deplorable state.

\section{References}

Abdih, Y., \& Medina, L. (2016). The informal economy in the Caucasus and Central Asia: Size And determinants. In A. Sauka, F. Schneider, \& C. C. Williams (Eds.), Entrepreneurship and the Shadow Economy. Edward Elgar Publishing Inc.

Anwar, S., Akbar, R., Akbar, M. W., \& Azhar, A. (2017). Measuring the size of underground Economy in Pakistan: A microeconomic approach. Journal of Applied Environmental and Biological Sciences, 7(8), 84-93.

Aruoba, S. B. (2010). Informal Sector, Government Policy and Institutions. 2010 Meeting Papers 324, Society for Economic Dynamics.

Awasthi, R., \& Engelschalk, M. (2018). Taxation and the shadow economy. How the tax system Can stimulate and enforce the formalization of business activities. Policy Research Working Paper 8391, World Bank Group Governance Global Practice.

Barbara, A., \& Claudio, C. (2015). Tax reforms and the underground economy: A simulation-Based analysis. Dipartimento di Economia, Diritto e Istituzioni, Universit`a degli Studi di Roma Tor Vergata, Via Columbia 2, 00133 Rome, Italy.

Bird, R., Martinez-Vasquez, J., \& Torgler, B. (2008). Tax effort in developing countries and high Income countries: The impact of corruption, Voice Accountability. Economic Analysis and Policy.

Bologna, J. (2015). The effect of informal employment and corruption on income levels in Brazil. Journal of Comparative Economics, 44(3), 657-695. https//doi.org/10.1016/j.jce.2015.12.001

Borlea, S. N., Achim, M. V., \& Miron, M. G. A. (2017). Corruption, shadow economy and economic Growth: An empirical survey across the European Union Countries. Studia Universitatis "Vasile Goldis" Arad - Economic Series, 27(2), 19-32. http//doi.org/10.1515/sues-2017-0006

Chen, H., \& Schneider, F. (2018). Size and causes of shadow economy in China over 1978-2016: Based on the currency demand method. Retrieved Aril 6, 2019, from https://www.econ.jku.at/t3/.../schneider/.../Chen_Schneider_2018_Sizeandcausesofshadow.p

Feige, E. L., \& Urban, I. (2008). Measuring Underground (Unobserved, Non-Observed, Unrecorded) Economies in Transition Countries: Can We Trust GDP?. Michigan: The William Davidson Institute.

Gaspareniene, L., Remeikiene, R., \& Heikkila, M. (2016). Evaluation of the impact of shadow Economy determinants: Ukrainian case. Intellectual Economics, 10, 108-113. https://doi.org/10.1016/j.intele.2017.03.003

Guillermo, R. B. C., \& Deyvi, A. A. (2018). The informal economy and its impact on tax revenues And economic growth. Analysis of OECD members and Latin America Countries (1995-2016). Retrieved March 20, 2019, from https://www.researchgate.net/publication/328343445

Gujarati, D. N., \& Porter, D. C. (2009). Basic Econometrics (5th ed.). Boston: McGraw-Hill Irwin.

Hassan, M. (2017). The impact of the shadow economy on aid and economic development nexus in Egypt. Munich Personal RePEc Archive. Retrieved from https://mpra.ub.uni-muenchen.de/80990/

Hunady, J., \& Orviska, M. (2015). The effect of corruption on tax revenue in OECD and Latin America countries. Retrieved March 22, 2019, from https://www.researchgate.net/publication/279188559 
International Monetary Fund. (2017). Nigeria's informal economy accounts for 65\% of GDP - IMF. Retrieved March 20, 2019, from https://www.businessamlive.com/nigerias-informal-economy-accounts-65-gdp-imf/

Ivanyna, M., Moumouras, A., \& Rangazas, P. C. (2016). The culture of corruption, tax evasion, and Economic Growth (January 2016). Economic Inquiry, 54(1), 520-542. https://doi.org/10.1111/ecin.12228

Mawejje, J., \& Munyambonera, E. F. (2016). Tax revenue effects of sectoral growth and public Expenditure in Uganda. Economic Policy Research Centre, Research Series No. 125.

Muchiri, K. B. (2014). An analysis of the effect of the growth of the informal sector on tax revenue Performance in Kenya. Msc. Thesis, the school of Economics, University of Nairobi.

Nchor, D., \& Konderla, T. (2016). The Shadow Economy of Czech Republic and Tax Evasion: The Currency Demand Approach. Acta Universitatis Agriculturae et Silviculturae Mendelianae Brunensis, 64(6), 2081-2086. https://doi.org/10.11118/actaun201664062081

Ogunc, F., \& Yilmaz, G. (2000, September). Estimating the Underground Economy in Turkey. Discussion paper, The Central Bank of the Republic of Turkey, Research Department.

Omodero, C. O. (2019). Government sectoral expenditure and poverty alleviation in Nigeria. Research in World Economy, 10(1), 80-90. https://doi.org/10.5430/rwe.v10n1p80

Omodero, C. O. (2019). Tax evasion and its consequences on an emerging economy: Nigeria as a Focus. Research in World Economy, 10(3), 127-135. https://doi.org/10.5430/rwe/v10n3p127

Omodero, C. O. (2019). The financial and economic implications of underground economy: The Nigerian Perspective. Academic Journal of Interdisciplinary Studies, 8(2), 155-167. https://doi.org/10.2478/ajis-2019-0027

Omodero, C. O., \& Dandago, K. I. (2018). Corruption and stock market performance in Nigeria. Annals of Spiru Haret University, Economic Series, 18(4), 23-40. https://doi.org/10.26458/1842

Omodero, C. O., \& Dandago, K. I. (2019). Tax revenue and public service delivery: Evidence from Nigeria. International Journal of Financial Research, 10(2), 82-91. https://doi.org/10.5430/ijfr.v10n2p82

Opret, L. A., Turcas, F. M., Dumiter, F. C., \& Brezeanu, P. (2017). Tax evasion between fraud and Legality. Studia Universitatis "Vasile Goldis" Arad - Economic Series, 27(4), 1-11. https://doi.org/10.1515/sues-2017-0013

Peter, L. (2017). Investigating the impact of the shadow economy on tax revenue performance in Zimbabwe (1980-2015). Bsc. Project, Department of Economics, Faculty of Commerce, Midlands State University, Gweru, Zimbabwe.

Petrescu, I. M. (2016). The Effects of Economic Sanctions on the Informal Economy. Management Dynamics in the Knowledge Economy, 4(4), 623-648.

Putnins, T. J., \& Sauka, A. (2014). Measuring the Shadow Economy Using Company Managers. Journal of Comparative Economics. Retrieved from https://ssrn.com/abstract=2423253

Schneider, F. (2010). The influence of public institutions on the shadow economy: An empirical Investigation for OECD Countries. European Journal of Law and Economics, 6(3), 441-468.

Schneider, F., \& Enste, D. (2000). Shadow Economies: size, causes and consequences. The Journal of Economic Literature, 38(1), 77-114.

Shahab, M. R., Pajooyan, J., \& Ghaffari, F. (2015). The effect of corruption on shadow economy: An empirical analysis based on panel data. International Journal of Business and Development Studies, 7(1), 85-100.

Tanzi, V. (1980). The underground economy in the United States: estimates and implications. Banca Nazionale del Lavoro, 135, 427-453.

Tanzi, V. (1983). The underground economy in the United States: annual estimates, 1930-1980. IMF Staff Papers, 30, 283-305.

Tanzi, V. (1999). Uses and Abuses of Estimates of the Underground Economy. Economic Journal, 109(3), 338-347.

Tatariyanto, F. (2014). Taxing the underground economy: The case of Indonesia. Journal of Economics and Sustainable Development, 5(27), 236-250.

Tedika, O., \& Mutascu, M. (2013). Shadow economy and tax revenue in Africa. Munich Personal RePEc Archive. Retrieved from http://mpra.ub.uni-muenchen.de/508121

Vuletin, G. J. (2008). Measuring the informal economy in Latin America and the Caribbean. Working Paper No. 08/102, International Monetary Fund. 